Metallophysics and Advanced Technologies

металофіз. новітні технол.

Metallofiz. Noveishie Tekhnol.

2020, vol. 42, No. 4, pp. 541-552

https://doi.org/10.15407/mfint.42.04.0541

Reprints available directly from the publisher
(C) 2020 G. V. Kurdyumov Institute for Metal Physics, National Academy of Sciences of Ukraine Published by license under

the G. V. Kurdyumov Institute for Metal PhysicsN.A.S. of Ukraine Publishers imprint. Printed in Ukraine.

PACSnumbers: 62.20.Qp, 68.55.J-, 68.55.Nq, 81.05.Bx, 81.20.-n, 81.40.Pq, 82.33.Vx

\title{
Composite Material for Hardening of Tillage Machines Working Bodies Containing Titanium and Chromium Borides Synthesized Using SHS-Process
}

\author{
S. A. Luzan, A. I. Sidashenko, and A. S. Luzan \\ Kharkiv Petro Vasylenko National Technical University of Agriculture, \\ 44 Alchevskykh Str., \\ UA-61002 Kharkiv, Ukraine
}

The article presents results of the study of the developed composite material based on the powder of $\mathrm{Ni}-\mathrm{Cr}-\mathrm{B}-\mathrm{Si}$ system modified with the composite material obtained using the process of self-propagating high-temperature synthesis (SHS) and contained titanium and chromium borides. The microstructure of composite material weld overlay coatings is a matrix material-PG10N-01 alloy, where solid inclusions such as titanium diboride and chromium boride are uniformly distributed. As found, the composite material has high abrasive wear resistance and can be recommended for hardening of tillage machines working bodies.

Key words: composite material, mechanical activation, SHS-process, overlay welding (surfacing), wear resistance.

\begin{abstract}
Представлено результати дослідження розробленого композиційного матеріалу на основі порошкової системи $\mathrm{Ni}-\mathrm{Cr}-\mathrm{B}-\mathrm{Si}$, модифікованої композиційним матеріалом, отриманим із застосуванням процесу самопоширюваного високотемпературного синтезу (CBC) і вміщуючим бориди титану і хрому. Мікроструктура наплавлених покриттів з композиційного матеріалу являє собою матричний матеріал - стоп ПГ-10Н-01, в якому рівномірно розподілені тверді включення: диборид титану і борид хрому. Встановлено, що композиційний матеріал має високу абразивну зносостійкість і може бути рекомендований для зміцнення робочих органів грунтообробних машин.
\end{abstract}

Corresponding author: Sergey Alexeevich Luzan

E-mail: khadi.luzan@gmail.com

Citation: S. A. Luzan, A. I. Sidashenko, and A. S. Luzan, Composite Material for Hardening of Tillage Machines Working Bodies Containing Titanium and Chromium Borides Synthesized Using SHS-Process, Metallofiz. Noveishie Tekhnol., 42, No. 4: 541-552 (2020), DOI: 10.15407/mfint.42.04.0541. 
Ключові слова: композиційний матеріал, механоактивація, СBC-процес, наплавка, зносостійкість.

Представлены результаты исследования разработанного композиционного материала на основе порошковой системы $\mathrm{Ni}-\mathrm{Cr}-\mathrm{B}-\mathrm{Si}$, модифицированной композиционным материалом, полученным с применением процесса самораспространяющегося высокотемпературного синтеза (CBC) и содержащим бориды титана и хрома. Микроструктура наплавленных покрытий из композиционного материала представляет собой матричный материал - сплав ПГ-10Н-01, в котором равномерно распределены твёрдые включения: диборид титана и борид хрома. Установлено, что композиционный материал обладает высокой абразивной износостойкостью и может быть рекомендован для упрочнения рабочих органов почвообрабатывающих машин.

Ключевые слова: композиционный материал, механоактивация, CBCпроцесс, наплавка, износостойкость.

(Received March 21, 2019; in final version, February 27, 2020)

\section{INTRODUCTION}

The reason of machine parts low service life is mainly related to wear and their surface layers corrosive damage. Agricultural machines working bodies function in contact with abrasive medium, parts of various mechanisms and devices often interact with aggressive medium, technological mediums used in the production process of products manufacturing. Therefore, the problem of creating effective protective coatings on the surface of machine parts is relevant.

At present, the method of obtaining powder materials by selfpropagating high-temperature synthesis (SHS) with preliminary mechanical activation treatment of the constituent components is being actively developed. Such mechanical activation of powder reacting mixtures is an effective way to control solid-flame combustion reaction for the synthesis of inorganic materials. This technology has been developed in advanced foreign countries: USA, Japan, China, Poland, Russia, Belarus etc.

The work addressed the problem of developing a composite material for weld overlay of coatings designed to increase the service life of the restored tillage machines working parts. The main idea of the proposed approach is to increase the wear resistance of $\mathrm{Ni}-\mathrm{Cr}-\mathrm{B}-\mathrm{Si}$ system alloy coatings by introducing titanium diboride and chromium boride synthesized using the SHS process into the overlaying mixture. As the matrix material, it is proposed to use a commercially produced in Ukraine nickel-based powder of the brand PG-10N-01 TUU 322-19004-96, coatings made of this have high strength and hardness after overlaying welding, but their wear resistance under dry friction condi- 
tions is not high enough and therefore, modification of the overlay material is required.

\section{A REVIEW OF THE PROBLEM}

To the solving of the problem of increasing of strength and performance properties of product materials exposed to intense wear by means of a directional modifying effect of the dispersed refractory compounds introduced into the melt obtained by various methods, including the use of the SHS-process, are dedicated works [1-3].

The use of methods of mechanical activation allows synthesizing materials with higher physicochemical and mechanical properties. As a result of the mechanical impact, in the metal arise internal stresses, there also takes place the formation and accumulation of crystal lattice defects. When processing materials in ball mills, the conditions are created for the flow of mechanochemical reactions directly in them or during the subsequent thermal activation of transformations in mechanocomposites obtained by the activation of two or more components [4].

Metallic systems can be a diluent matrix of the reaction mixture. Besides diffusional difficulties, spatial separation of components and following reaction products, metal matrix is involved in heat removal processes, which is especially important for exothermic reactions. The introduction of a diluent metal into the reaction mixture lowers the temperature that develops during the reaction, changing the conditions of the product crystallization [4].

The results of the significant amount of experimental works indicate the prospects of hardening phase synthesis directly in the presence of a metal [5]. While carrying out the reaction in the metal matrix, it is possible to obtain fine particles of the product and ensure their uniform distribution in the matrix.

Recently, a new class of composite materials has been created for detonation spraying of protective coatings consisting of a metal matrix and containing, as a strengthening disperse phase, synthesized nanosized (grain size about 15-40 $\mathrm{nm}$ ) ceramic particles uniformly distributed in the volume. It has been developed the scientific bases for the production of mechanochemical multicomponent composites of the type: $\mathrm{TiC}+\mathrm{UDA}+\mathrm{Ni}-\mathrm{Cr}, \mathrm{TiC}+\mathrm{WC}+\mathrm{Ni}-\mathrm{Cr}, \mathrm{TiB}_{2}+\mathrm{WC}+\mathrm{Ni}-\mathrm{Cr}, \mathrm{TiB}_{2}+$ $+\mathrm{Cu}, \mathrm{TiB}_{2}+\mathrm{Ti}-\mathrm{Ni}, \mathrm{TiB}_{2}+\mathrm{Ti}-\mathrm{Al}_{3}[6]$.

It has been developed multi-carbide SHS-mechanocomposites, which are new composite materials with a 'strengthening phase-matrix' type structure. Application of compositions $\mathrm{TiC}+(\mathrm{Ni}-\mathrm{Cr}), \mathrm{TiC}+\mathrm{SiC}+(\mathrm{Ni}-$ $\mathrm{Cr}), \mathrm{TiC}+\mathrm{WC}+(\mathrm{Ni}-\mathrm{Cr}), \mathrm{TiC}+\mathrm{SiC}+\mathrm{WC}+(\mathrm{Ni}-\mathrm{Cr})$ using a powder electrode allows forming a wear-resistant coating on machine parts [7].

The purpose of this work is to develop a composite material (CM) 
based on $\mathrm{Ni}-\mathrm{Cr}-\mathrm{B}-\mathrm{Si}$ system powder material, modified with a composite material (MCM) obtained using the SHS-process, containing titanium and chromium borides for hardening tillage machines working bodies by overlay welding.

\section{MATERIALS AND RESEARCH TECHNIQUES}

Boron is one of the most efficient and economical microalloying elements of steel. In most cases, the minimum concentration of boron in the metal to obtain a positive result is about one thousandth of a mass fraction of percentage. The uniqueness of boron lies in the fact that with such a small content in steel, it is able to influence its properties, equivalently to the action of a much larger number of such alloying elements as $\mathrm{Cr}$, Mo, Ni etc.

The traditional material used for boron alloying of steel is ferroboron. The long-term practice of using ferroboron has shown that it is quite difficult to carry out boron microalloying of steel with it. This is due, primarily, to the high reactivity of boron in the steel melt and its high chemical affinity with oxygen and nitrogen. In addition, in most cases it is required to provide an extremely low concentration of dissolved boron in the metal.

Therefore, when obtaining a composite material, we will synthesize titanium diboride using the SHS-process [8]:

$$
\mathrm{Ti}+2 \mathrm{~B}=\mathrm{TiB}_{2}+295 \mathrm{~kJ} / \mathrm{mol} \text {. }
$$

In addition, high exothermic effect of the reaction of titanium carbide formation should be noted:

$$
\mathrm{Ti}+\mathrm{C}=\mathrm{TiC}+310 \mathrm{~kJ} / \mathrm{mol} .
$$

As a result of the heat released, the temperature of solid and molten reaction products reaches $2500-3500 \mathrm{~K}$, so the reaction does not depend on external heat sources and can spread as a combustion wave, which itself produces energy for its spreading.

As a part of the conducted research, the compositions of the initial powder mixtures and the modes of their mechanical activation were worked out to obtain composite materials for overlay welding.

Titanium powders of grade VT1-0, boron B and PM-15 carbon were used as starting materials for the composite material production. In addition, to increase the thermal effect of the SHS-process, PT-NA-01 thermo-reactive nickel aluminide powder, GOST 5494-95 PAP-1 aluminium powder and $\mathrm{Fe}_{2} \mathrm{O}_{3}$ iron oxide were introduced into the mechanical mixture. The fractional composition of all the initial powder components was within 63-100 microns. The ratio of components in the 
mixture was equimolar so that, as a result of the subsequent SHSreaction, stoichiometric borides were synthesized.

The selected components were mixed, and the resulting powder mixture was subjected to mechanical activation, which was carried out in AGO-2 planetary ball mills. In carried out experiments the volume of the drums was $160 \mathrm{~cm}^{3}$, the diameter of the balls was $4-5 \mathrm{~mm}$, the mass of the balls was $200 \mathrm{~g}$. The time of the mechanical activation process varied from 2 to 6 minutes.

Obtaining a composite material was carried out in two stages: 1) mixing of powders $\mathrm{Ti}, \mathrm{B}, \mathrm{C}, \mathrm{Fe}_{2} \mathrm{O}_{3}$, Al, PT-NA-01, 30\% matrix material PG-10N-01 and their joint mechanical activation, adding a binderglue of 'Methylan' brand, cylinder forming and drying, the SHSprocess initiating, during which titanium, chromium etc. boride particles are synthesized; 2) cake fragmentation and mixing the obtained powder with PG-10N-01 TUU 322-19-004-96 industrial powder, mechanical activation of the obtained powder mixture; adding GOST 13078-81 liquid glass into the mechanically activated powder mixture before it turns into paste state.

The prepared paste was applied on the steel plate surface prepared for overlay welding (Steel 20), and after drying, it was carried out with overlay welding with a graphite electrode $10 \mathrm{~mm}$ in diameter, welding current was 80-120 A, and straight polarity.

Arc surfacing was carried out using Patton VDI-200P DC TIG inverter power supply.

The structure was studied using metallographic microscope MIM-8.

Coatings microhardness was measured on a DMH-3 hardness tester according to GOST 9450-76.

Comparative tests on wear of the overlaid samples were carried out on MI friction machine according to the 'disc-block' scheme in the medium of I-20 industrial oil under the following modes: average circumferential sliding speed was $0.42 \mathrm{~m} / \mathrm{s}$, unit pressure on the block during normal mechanochemical wear process was $8.0 \mathrm{MPa}$, friction surface area was $1.8 \mathrm{~cm}^{2}$.

Tests for abrasive wear of studied materials under conditions of friction on fixed abrasive particles were estimated according to GOST 17367-71.

The phase composition of overlays was determined using DRON-3 diffractometer in monochromatic $\mathrm{Cu} K_{\alpha}$ radiation in the angular interval $2 \theta=10-80^{\circ}$. ASTM card files data were used while deciphering diffraction patterns.

\section{RESULTS AND DISCUSSION}

The SHS of modifying composite material (MCM) was carried out on cylindrical samples under conditions of frontal synthesis. Ignition of 
the reacting composition was carried out by an electric arc (Figs. 1, 2).

Having obtained the modifying composite material in the form of a cake (Fig. 2, b), it was fragmented, PG-10N-01 matrix material was added in the amount of $80-90 \%$ and mechanical activation was carried out (Fig. 3).

The microstructure of deposited coatings with composite material has a very uniform structure with a uniform distribution of reinforcing particles over the coating volume (Fig. 3).

The results of the study of the overlaid coatings microhardness of composite materials composition $\{10 \% \mathrm{MCM}+90 \% \mathrm{PG}-10 \mathrm{~N}-01\}$ and $\{20 \% \mathrm{MCM}+80 \% \mathrm{PG}-10 \mathrm{~N}-01\}$ confirm that hard inclusions are present in the overlay. So microhardness of the overlaid coatings containing MCM exceeds the microhardness of PG-10N-01 overlaid coating, equal to $520 \mathrm{HV}$, and is $740 \mathrm{HV}$ for a coating containing $10 \% \mathrm{MCM}$ and $978 \mathrm{HV}$ at a content of $20 \% \mathrm{MCM}$, respectively, Rockwell hardness is 34, 40, 50 HRC.

Measurements of the coercive force in the weld rollers on steel 20, made using KRM-D-K2M structuroscope according to the industry standard SOU29.32.4-37-532: 2006, showed that while surfacing PG$10 \mathrm{~N}-01$ powder, its value was $H_{c}=4.9 \mathrm{~A} / \mathrm{cm}$, and while surfacing com-

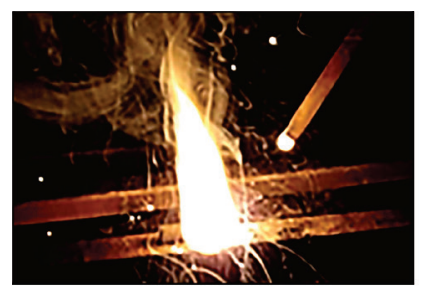

$a$

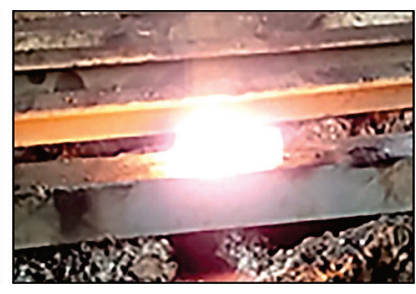

$b$

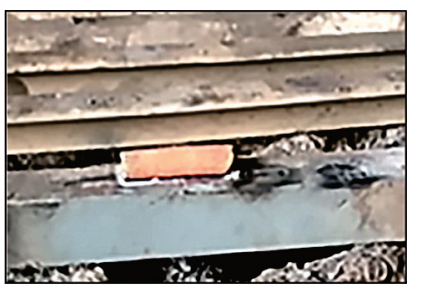

$c$

Fig. 1. SHS-process of formation of MCM from components Ti, B, C, $\mathrm{Fe}_{2} \mathrm{O}_{3}$, Al, PT-NA-01, PG-10N-01, stages: $a$-initial; $b$-maximum burning; $c-$ final.

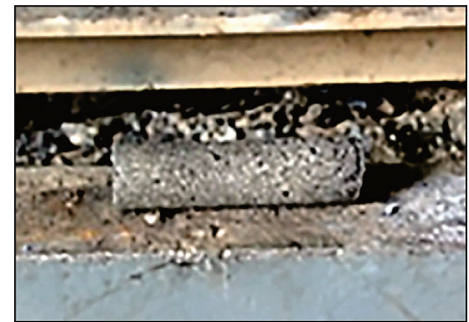

$a$

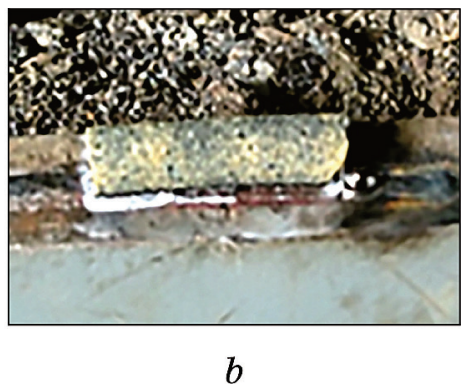

b

Fig. 2. MCM after: $a$-molding; $b$-SHS-process. 
posite materials $-H_{c}=5.1-5.8 \mathrm{~A} / \mathrm{cm}$ and $H_{c}=6.4-7.3 \mathrm{~A} / \mathrm{cm}$, containing 10 and $20 \%$ of the modifying composite material, respectively. The observed increase in the coercive force also confirms the presence of non-metallic solid components in the composite material structure.

According to the results of X-ray phase analysis, we can make a conclusion that these are particles of titanium diboride $\left(\mathrm{TiB}_{2}\right)$, chromium boride (CrB), etc. (Fig. 4).

The study of the microstructure of overlaid coatings on a scanning electron microscope JSM-6390LV with an energy dispersion detector $\mathrm{X}-\mathrm{Max}^{\mathrm{N}}$ showed that it has a typical morphology, which is formed on the metal surface during crystallization with directed heat removal. Scanning electron microscopy with X-ray microanalysis confirmed the phase inhomogeneity of the deposited layer at the micro level (Fig. 5).

Chemical composition 1-3 indicates the presence of elements $\mathrm{B}, \mathrm{O}$, $\mathrm{Ti}, \mathrm{Ni}$ in the coating (Fig. 5). This confirms the results of X-ray phase analysis, which established the presence of phases, $\mathrm{TiB}_{2}, \mathrm{CrB}, \mathrm{Ni}_{3} \mathrm{~B}$, TiO (Fig. 4).

$\mathrm{X}$-ray maps of the distribution of the main elements indicate a fairly uniform distribution of $\mathrm{Ti}, \mathrm{Cr}, \mathrm{Ni}, \mathrm{C}$ in the deposited coating (Fig. 6).

Figure 7 shows the wear tests results of PG-10N-01 coatings and composite material $\{20 \% \mathrm{MCM}+80 \% \mathrm{PG}-10 \mathrm{~N}-01\}$ on friction machine MI according to a disc-block scheme in the industrial oil medium with the unit load of $8 \mathrm{MPa}$.

Test results indicate higher wear resistance of the proposed composite material $\{20 \% \mathrm{MCM}+80 \% \mathrm{PG}-10 \mathrm{~N}-01\}$, which is 2.35 times higher than the wear resistance of the self-fluxing alloy of the PG-10N-01 brand.

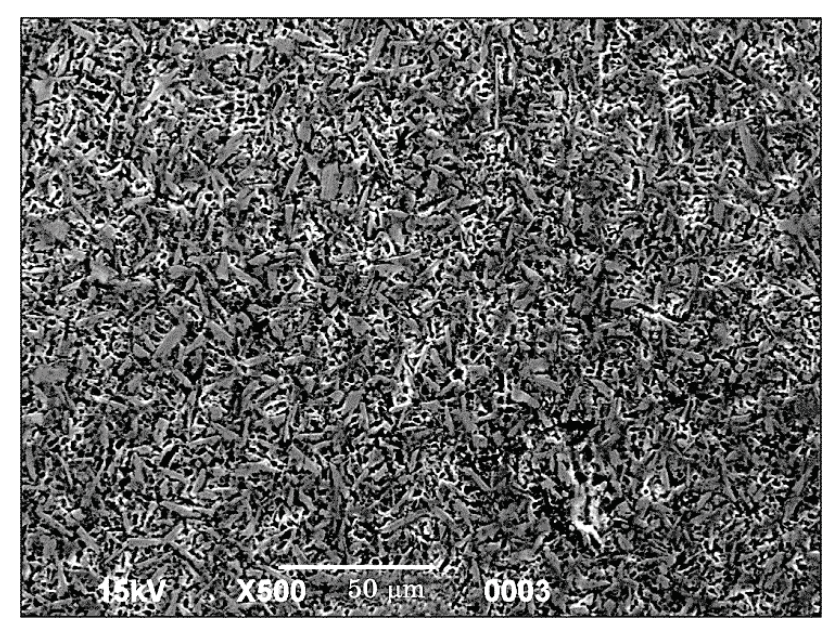

Fig. 3. Microstructure of deposited coatings with composite material $\{20 \%$ $\mathrm{MCM}+80 \%$ PG-10N-01\}. 


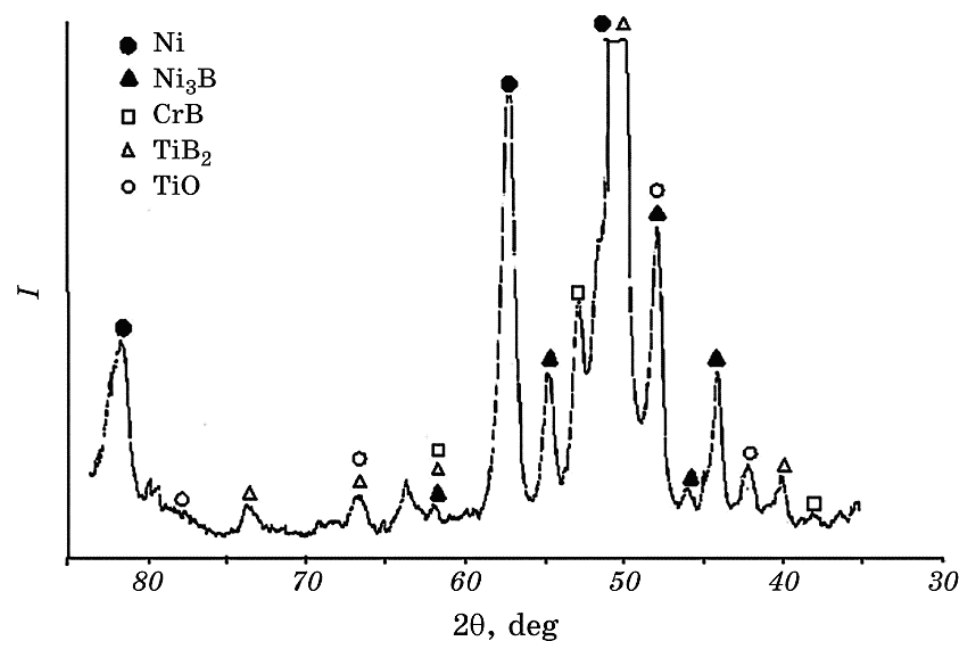

Fig. 4. X-ray diffraction pattern of the overlay with a composite material of $20 \% \mathrm{MCM}+80 \%$ PG-10N-01.

The wear resistance of the materials under study was also assessed by the results of friction tests on fixed particles according to GOST 17367-71. PG-10N-01 alloy was taken as a control material, its wear resistance was taken as a unit. The results are presented in Fig. 8.

The presence of titanium diboride $\left(\mathrm{TiB}_{2}\right)$, chromium boride $(\mathrm{CrB})$ and nickel boride $\left(\mathrm{Ni}_{3} \mathrm{~B}\right)$ in the overlaid coating leads to wear rate decrease. The wear resistance of the composite material $\{20 \% \mathrm{MC}+80 \%$ PG-10N-01\}, obtained by powder mixture surfacing, is 1.7 times high-

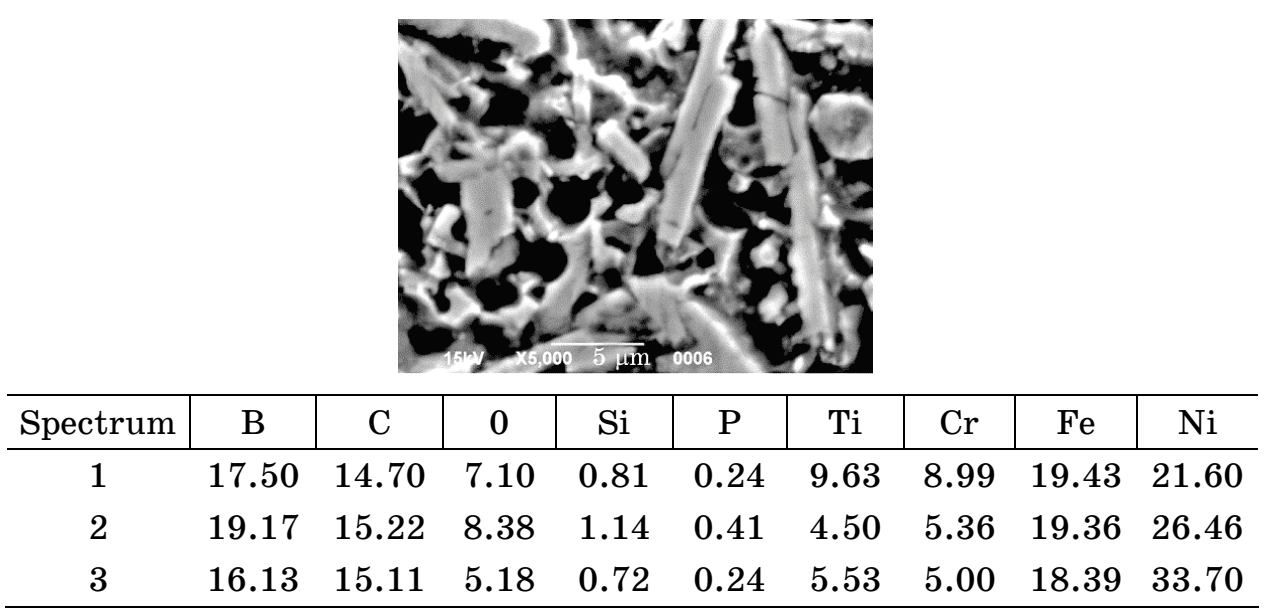

Fig. 5. Microstructure and chemical composition (\% wt.) overlaid coating CM $\{20 \% \mathrm{MCM}+80 \%$ PG-10N-01\}. 
er than the wear resistance of self-fluxing PG-10N-01 alloy.

Test results of overlay materials by definition of toughness, were

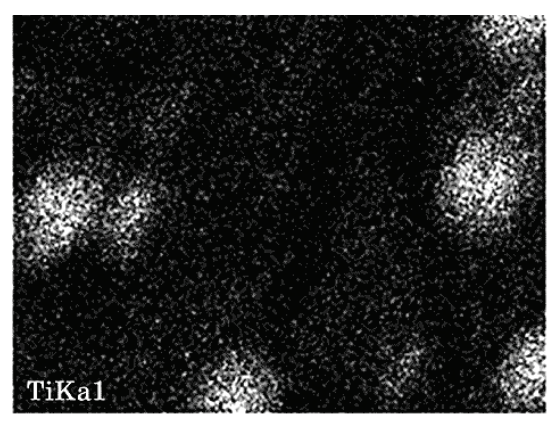

$a$

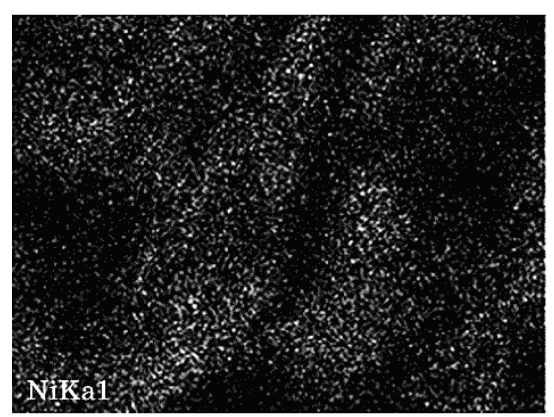

$c$

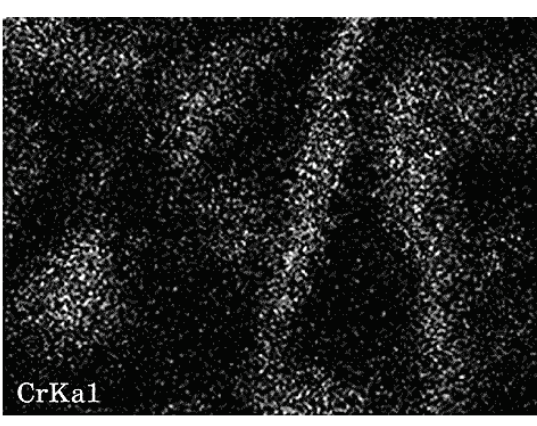

$b$

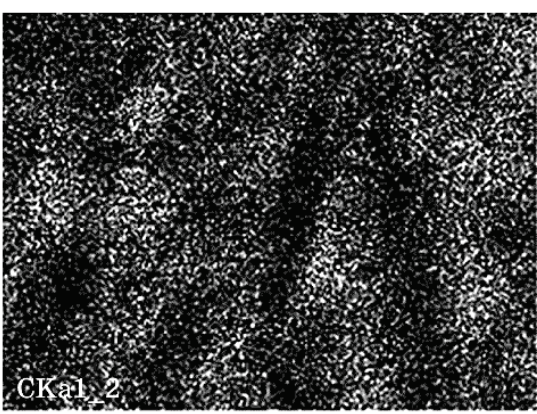

$d$

Fig. 6. Distribution of elements in the coating: $a-\mathrm{Ti}, b-\mathrm{Cr}, c-\mathrm{Ni}, d-\mathrm{C}$.

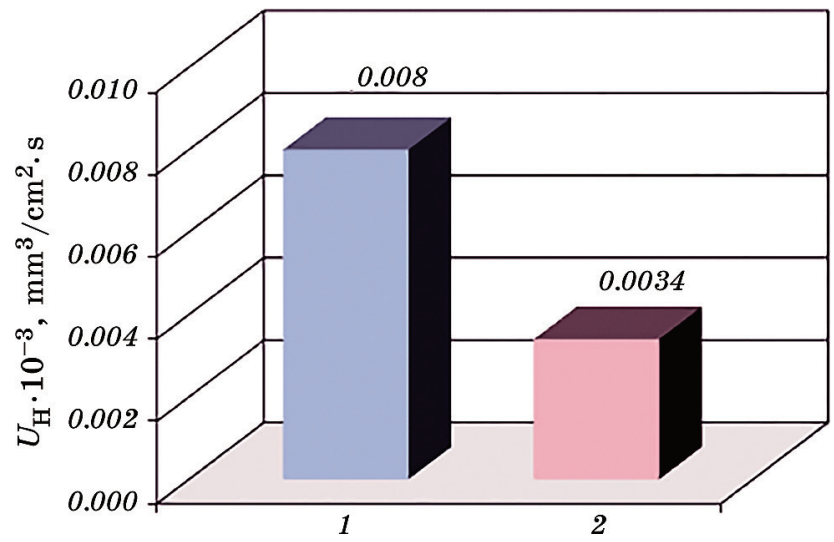

Fig. 7. Wear intensity in the process of normal friction in the medium of industrial oil steam: coating PG-10N-01-steel 45 HRC 50 (1); coating with composite material $\{20 \% \mathrm{MCM}+80 \% \mathrm{PG}-10 \mathrm{~N}-01\}$-steel 45 HRC 50 (2). 
carried out according to GOST 6996-66 'Welded joints. Methods of mechanical properties determination' are presented in Table 1.

From Table 1 it can be seen that with an increase in the content of MCM, the toughness of overlaid coating decreases.

To create the interconnection of overlay welding modes with the properties of overlaid materials, the effective heat input value was determined. The calculations were carried out according to the formula (GOST R ISO 857-1-2009):

$$
q_{n}=\frac{I U}{V_{n}},
$$

where $I$-current strength, A, $U$-arc voltage, $\mathrm{V}, V_{n}$-overlay welding rate, $\mathrm{cm} / \mathrm{s}$. The calculation results are summarized in Table 2.

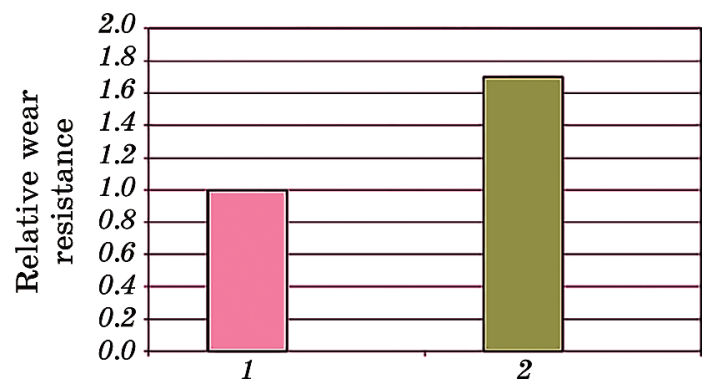

Fig. 8. Relative wear resistance of materials surfaced by the electric arc method under the influence of fixed abrasive particles: $1-\mathrm{PG}-10 \mathrm{~N}-01$ alloy; 2 -composite material $\{20 \% \mathrm{MCM}+80 \% \mathrm{PG}-10 \mathrm{~N}-01\}$.

TABLE 1. Toughness of overlaid composite materials.

\begin{tabular}{c|c|c}
\hline No. ser. & Composite material & Middle value $K C V, \mathrm{~J} / \mathrm{cm}^{2}$ \\
\hline 1 & $10 \%$ MCM + 90\% PG-10N-01 & 4.5 \\
2 & $20 \%$ MCM + 80 $\%$ PG-10N-01 & 3.2 \\
3 & $30 \%$ MCM + 70\% PG-10N-01 & 2.1 \\
\hline
\end{tabular}

TABLE 2. The calculation of the effective heat input while surfacing a composite material of the composition $20 \% \mathrm{MCM}+80 \% \mathrm{PG}-10 \mathrm{~N}-01$.

\begin{tabular}{ccccc}
\hline Current strength, A & Voltage, $\mathrm{V}$ & Overlay welding rate, $\mathrm{cm} / \mathrm{s}$ & Heat input, $\mathrm{kJ} / \mathrm{cm}$ \\
\hline 150 & 40 & 0.15 & 40.00 \\
200 & 31 & 0.20 & 31.00 \\
250 & 20 & 0.25 & 20.00 \\
\hline
\end{tabular}




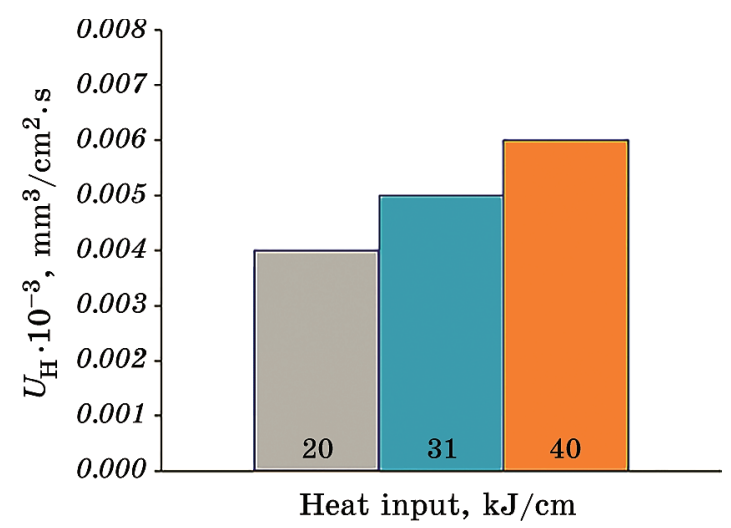

Fig. 9. Wear rate change depending on the amount of heat input while composite materials surfacing of the composition $20 \% \mathrm{MCM}+80 \%$ PG-10N-01.

The temperature of the melting bath increases, with the increase of heat input, which contributes into boride particles dissolution. This is evidenced by wear rate increase of overlaid samples (Fig. 9).

Thus, based on the obtained results of the research, it is possible to recommend surfacing with a welding current of $250 \mathrm{~A}$ and overlay welding rate of $2.5 \mathrm{~mm} / \mathrm{s}$.

\section{CONCLUSIONS}

1. A composite material based on a self-fluxing alloy of $\mathrm{Ni}-\mathrm{Cr}-\mathrm{B}-\mathrm{Si}$ system (PG-10N-01 powder), modified with a mechanically activated composite material obtained using the SHS-process, was developed for hardening the working bodies of tillage machines.

2 . The microstructure of overlaid coatings is a matrix material-PG10N-01 alloy, in which solid inclusions such as titanium diboride, chromium and nickel borides are uniformly distributed. Microhardness of overlaid coatings containing MCM exceeds the microhardness of PG-10N-01 overlay, equal to $520 \mathrm{HV}$, and is $740 \mathrm{HV}$ for a coating containing $10 \%$ MCM, $978 \mathrm{HV}$ with a content of $20 \%$ MCM. Rockwell hardness is equal to $34,40,50 H R C$, respectively.

3. It was found out that composite material has higher wear resistance than PG-10N-01 alloy in the process of normal friction in industrial oil medium, also under the condition of fixed abrasive particles input for composite material of composition $20 \% \mathrm{MKM}+80 \%$ ПГ-10H-012.35 and 1.7 times, respectively.

4. It was found that with the increase in the content of MCM composite material, the toughness decreases.

5. While surfacing composite material the increase of heat input leads to its wear rate increase. Therefore, the surfacing of the developed 
composite material of composition $20 \% \mathrm{MCM}+80 \%$ PG-10N-01 is recommended to be carried out with welding current of $250 \mathrm{~A}$ and overlay welding rate of $2.5 \mathrm{~mm} / \mathrm{s}$.

\section{REFERENCES}

1. Yu. N. Saraev, V. P. Bezborodov, A. A. Shtertser, V. Yu. Ulianitskyi, A. M. Orishich, A. F. Ilyushchenko, and M. K. Skakov, Svarochnoe Proizvodstvo, No. 7: (2011) (in Russian).

2. A. M. Stolin, P. M. Bazhin, M. V. Miheev, O. A. Averichev, A. S. Sahidollaev, and K. T. Kylyshbaev, Svarochnoe Proizvodstvo, No. 8: (2014) (in Russian).

3. A. P. Mukhachev and O. A. Kharytonova, Metallofiz. Noveishie Tekhnol., 39, No. 10: 1395 (2017) (in Russian).

4. K. A. Taiasov, V. P. Isupov, and B. B. Bokhonov, J. Mater. Synth. Proc., 8, No. 1: (2000).

5. A. H. Merzhanov and A. S. Mukasyan, Tverdoplamennoe Gorenie [Solid Flame Burning] (Moscow: TORUS PRESS: 2007) (in Russian).

6. V. I. Yakovlev, Nauchno-Tekhnologicheskie Osnovy Sozdaniya Zashchitnykh Pokrytiy iz Kompozitsionnykh Mekhanoaktivirovannykh SVS-Materialov Metodom Detonatsionno-Gazovoho Napyleniya [Scientific and Technological Bases of Protective Coatings Creation from Composite Mechanically Active SHS Materials by the Method of Detonation Gas Spraying] (Thesis of Disser. for Dr. Tech. Sci.) (Moscow: 2008) (in Russian).

7. A. V. Sobachkin, Formirovanie Iznosostoykikh Pokryitiy dlya Detaley Selskohozyaystvennogo Mashinostroeniya pri Elektrodugovoy Naplavke Mnogokomponentnykh Mekhanoaktivirovannykh SVS-Materialov [Formation of Wear-Resistant Coatings for Agricultural Machinery Parts During Electric Arc Surfacing of Multicomponent Mechanically Activated SHS Materials] (Thesis of Disser. for Cand. Tech. Sci.) (Barnaul: 2013) (in Russian).

8. A. S. Rogachev, and A. S. Mukasyan, Gorenie dlya Sinteza Materialov: Vvedenie $v$ Strukturnuyu Makrokinetiku [Combustion for the Synthesis of Materials: an Introduction to Structural Macrokinetics] (Moscow: FIZMATLIT: 2013) (in Russian). 